\title{
EXPLOITING SOCIAL NETWORKING SITES FOR ENCOURAGING EMPLOYEE PARTICIPATION IN TRADE UNIONS: A NEW PERSPECTIVE
}

\author{
Bimal Chandra Nayak, Gopal Krishna Nayak and Debasish Jena \\ International Institute of Information Technology, Bhubaneswar, Odisha, India
}

\begin{abstract}
$A$ review of the existing literature suggests that although most industrialized countries have seen a drop in union membership rates, in past years, the drop in union density (the unionized proportion of the working population) has been more significant in the Indian context. Some popular explanations that pin this decline to the reduced popularity of unionization among workers and the general public include the small size of unions, multiplicity of trade unions and rivalries, leadership issues, the politicization of trade unions, etc. One of the major causes, why the new age industrial worker does not covet to join a trade union, is the lack of knowledge of trade unions and the advantage of joining trade unions. The current study is an effort in this direction, where it has been argued that Social networking sites (a new mode of social network concept) can be used as an effective tool by unions for informing/convincing workers of unionism's benefits, which is otherwise difficult to perceive without experience. Social networking sites also can be leveraged by the trade unions to increase their union membership by reaching out to more and more employees as well as creating a brand image for themselves. In this paper, based on the literature review and analysis, a framework linking employee participation, union membership, and social networking sites has been suggested, thus offering a new perspective of "social networking" in the industrial relations area.
\end{abstract}

Key words: Trade Unions, Union Membership, Industrial Relations, Union Density, Social Network, and Social Networking Sites.

Cite this Article: Bimal Chandra Nayak, Gopal Krishna Nayak and Debasish Jena, Exploiting social networking sites for encouraging Employee Participation in Trade Unions: A new perspective, International Journal of Management, 11(12), 2020, pp 2045-2052.

http://iaeme.com/Home/issue/IJM?Volume=11\&Issue=12 


\section{INTRODUCTION}

A trade union is an organization of workers who have joined together to achieve common goals in key areas such as working conditions, collective bargaining on remunerations, and other benefits. Following the definition of the Australian Bureau of Statistics, a trade union may be defined as "an organization, consisting predominantly of employees, the principal activities of which include the negotiation of pay and conditions of employment for its members" or, slightly different, as 'an organization which consists wholly or mainly of workers and whose principal purposes includes the regulation of relations between workers and employers or employer's associations.' [25]. According to this report, an 'a union member is a person who self-defines that he or she belongs to a labor union, employee, or staff organization or a person who pays his or her dues and is recognized as a member by a union organization'. There is a serious declining trend that has been observed in union membership in most industrialized nations since the early 1990 s.

In most previous studies, mainly two possible ways of looking at union membership figures have been acknowledged. The first method is simply adding up all union members in a factory, office, or country. This gives an overall membership position. In the second method, the density of membership is calculated. Density is the percentage of union members concerning total employment. For example, if unions have 50 members in a factory employing 100 , the density is 50 percent. When the reference is to the entire country, density is measured by comparing union members against total employment in all sectors. Density is generally accepted as a better indicator because it shows not only how many are members but also how many are not. Today union density has lost its ground especially severely in the Englishspeaking countries. In the United Kingdom, union density has fallen by 15 points, in Australia by 12 points, and in Ireland and the United States by 10 points [26]. According to the [15] report (1997), union density has dropped stridently in many European countries. In France, which is the worst hit, the density of union membership is now estimated to be a miserable 10 percent. In Holland, which is also affected, density is estimated at around 25 percent. In England, the density of union membership is 44 percent. The picture is not quite different outside of Europe. In Japan, it has dropped to 25 percent. In India, union density has been incredibly low, at 10 percent.

\section{UNIONISM IN INDIA}

India is one of the promising developing countries with almost 120 crores of population. According to the World Labor Report 1997-98 [14], the Indian workforce of 31.479 Crores (314.79 million) constitutes 37.3 percent of the total population. Of the total workforce, 91.5 percent is accounted for by the informal sector, while the formal sector accounts for 8.5 percent. Further, only about 3 Crores (30 million) (i.e., 9.5 percent of the workforce) are employed permanently, implying 90.5 percent being employed on a casual basis. It has also been reported that by December 1991, the claimed membership of the Indian trade union movement was 3.05 Crores (30.5 million) (i.e., 9.68 percent of the workforce) with 82.24 percent of the trade union membership being accounted for by the organized sector. In terms of union density in the informal sector, India fares rather badly compared to other large developing countries. According to the [15], union membership as a percentage of non-agricultural labor dropped from 6.6 percent in 1985 to 5.5 percent in 1995 (the corresponding figure in 1995 for Argentina was 23.4 percent, Brazil 32.1 percent, and Mexico 31 percent). Union membership as a percentage of India's formal sector workers declined from 26.5 percent to 22.8 percent between 1985 and 1995 (the corresponding figures in 1995 were Argentina 65.6 percent, Brazil 66 percent, Mexico 72.9 percent). Thus, the unions meagerly represent the unorganized sector. 
According to the [15], the Indian economy is dominated by the services sector, which accounted for 53.7 percent of GVA in 2016-17. In terms of employment, the share of the services sector in urban areas was 58.7 percent (2011-12), compared to just 16.1 percent in rural regions. The share of industry (which consists of both manufacturing and construction), stood at 31.2 percent of GDP in 2016-17, as compared to 31.5 percent in the previous year. At the sectoral level, the construction and manufacturing sectors saw the sharpest decline and stood at 7.9 percent and 1.7 percent of GVA in 2016-17. The majority of workers in India are in informal employment. Behind this, there are two underlying but diverging trends. Firstly, the share of workers in the unorganized sector fell from 86.3 percent in 2004-05 to 82.2 percent in 201112.9. At the same time, the share of informal workers in the organized sector (i.e., workers without access to social security) increased significantly because of the greater use of contract and other forms of casual labor. The share of contract labor in organized manufacturing increased from 15.6 percent at the end of the 1990s to 34.7 percent in 2011-12. Seventy-nine percent of non-agricultural wage workers had no written contract, and only 23.8 percent were eligible for social security benefits. Because of these countervailing trends, the overall proportion of informal workers in total employment (e.g., unorganized sector workers plus informal workers in the organized sector) has remained relatively stable, at around 92 percent [15].

After 20 years, in 2019, many changes were incorporated in the organization including the way people were employed, the type of work employees do, and advancement of technologies and type of labors have been extensively observed; still, the trade union membership trend has not much changed. The World Employment and Social Outlook -Trends report in 2019 summarized the trade union situation in India "Indian unions are too very fragmented. In many workplaces, several trade unions compete for the loyalty of the same body of workers, and their rivalry is usually bitter and sometimes violent. It is difficult to say how many trade unions operate at the national level since many are not affiliated to any all- India federation. The early splits in Indian trade unionism tended to be on ideological grounds, each linked to a particular political party. Much of the recent fragmentation, however, has centered on personalities and occasionally on caste or regional considerations." Trade unionism in India suffers from a variety of problems such as politicization of the unions, the multiplicity of unions, inter-union rivalry, uneconomic size, financial debility, and dependence on outside leadership. Apart from these, unions are not in popular demand in India. The public is not against unionism in principle. It is against the way unions and union leaders' function. The public image of union leaders is that they are autocratic, corrupt, and indifferent to the public interest' Too much power, too little morality' sums up the publics' assessment of unions. Apart from this, some popular explanations that pin this decline to the reduced popularity of unionization among workers and the general public include the multiplicity of trade unions and rivalries and politicization of trade unions. In Indian manufacturing, contract labor reached 34.7 percent in 2011-12, up from negligible levels in the early $1970 \mathrm{~s}$. Studies reported that contract labor has risen to $60-70$ percent of" total employment in many manufacturing companies[22].

One of the major causes, why the new age industrial worker does not covet to join a trade union, is the lack of knowledge of trade unions, their roles, and the advantage of joining trade unions. Trade unions are only one of its kind organizations, whose role has always been variously interpreted and understood by diverse interest groups of the society. Traditionally trade unions' role has been to protect jobs and real earnings, safe and improved conditions of work as well as life, and fight against exploitation and arbitrariness, to ensure fairness and equity in employment contexts. In the wake of a long history of the union movement and accumulated benefits under collective agreements, a plethora of legislation and industrial jurisprudence, increasing literacy and awareness among the employees, and the spread of a variety of social institutions including consumer and public interest groups, the protective role 
of a trade union, has already undergone, a qualitative change. It can be said that the protective role of trade unions remains in form but varies in substance. On one side, trade unions, through industrial action (such as protests and strikes) and political action (influencing Government policy), establish minimum economic and legal conditions and restrain the abuse of labor wherever the labor is organized; on the other hand, trade unions are also seen as moral institutions, which can uplift the weak and downtrodden and render them the place, the dignity, and justice they deserve. But very few people are aware of this.

Specifically, in India, the new age workforce is always hesitant to join unions. Though there are many reasons for the decline of union membership in India- likely well known to many reading this article - but the author prefers to cast light on a somewhat less quantifiable cause, which is 'the trade unions in India are not successful in propagating their role and the advantages associated with being a trade union member.' Most of the young generation is not aware of the advantages of trade unions. Hence there exists a hesitation to join trade unions. Besides, [20] claim that "over the years, Indian trade unions have acquired an unfavorable perception of behaving irresponsibly, catering to vested interests, adopting disruptive tactics, neglecting the concerns of members and ignoring the welfare of society at large." They show that this negative image is used by employers in the IT industry to prevent or disrupt organizing efforts by portraying the trade unions as backward, unhelpful, irrelevant, or dangerous. This is another reason contributing to the declining trade union membership share. This is where comes the use of the second part of our title contains a potential and partial answer to the question. "Can anything be done to stem this decline? How to increase employee participation in trade unions? How trade unions can reach these young audiences?"

This paper argues that union must communicate and reach to every worker or employee (among many others) and must propagate the advantages of joining unions. A brand building of trade union is essential, Supportive social trends and social customs are required, and they should be leveraged to make union membership is many hard-to-observe benefits easier to communicate to its audience. Most membership-based institutions face the same dilemma. However, recent social networking organizations such as Twitter, Facebook, and other online communities have been rather successful in attracting millions of members in a relatively short period. The question of whether the union movement can be appropriate, some of these lessons are discussed here.

\section{SOCIAL NETWORKING SITES}

The notion of social networking site has come into existence with the web "and Internet revolution [16]. The concept has been derived from the social capital approach and social network theory [11]. Social network theory focuses on relationships among actors (i.e., individuals, work units, or organizations) and thereby distinguishes itself from more traditional organizational research perspectives that examine individual actors in isolation [4,23]. The central premise underlying social network theory is that actors are embedded within networks of interconnected relationships that provide opportunities for and constraints on behavior $[8,24]$. Both the structure and composition of these social networks have been proposed as potential sources of social capital. Social capital is defined as the aggregate of actual or potential resources which are linked to possession of a durable network of more or less institutionalized relationships of more or mutual acquaintance and recognition. Social capital has been acknowledged as a concept having significance to the study of "network social processes" $[1,19]$. According to [9], the structure of the network is important, especially in social capital formation. The original information can be obtained by exploiting a network composed of low redundant contacts. On the other hand, $[10,21,27]$ highlighted the importance of trust in the development of social capital. Supporting the importance of social networks, research has 
found social capital to be associated with the innovation, performance, and survival of groups and organizations, and with individual outcomes such" as work attitudes, job performance, and finding employment [9]. While social capital has received considerable attention in other areas of business, such as in assessing the linkages between organizational social capital and knowledge or value creation within the MNCs (e.g., 19) there has been relatively little research in the field of industrial relations discipline. In addition to this, even though studies on social networks have been conducted in fields like sociology and anthropology [3], recent developments in web and Internet tools provide a rich and unprecedented opportunity to reexamine some assumptions and findings concerning the structure and behavior of social networks in social networking sites and their usefulness in trade union participation.

\section{UNIONISM AND SOCIAL NETWORKING}

A social networking site is an online place where a user can create a profile and develop a personal network that connects him or her to other users. In the past five years, such sites have increased rapidly from a niche activity into a trend that holds tens of millions of Internet users. Social networking sites (like Facebook, Twitter, Orkut, LinkedIn, etc.) allowed people to communicate with their friends and exchange information. Once one becomes a member of these sites, he/she can select to join one or more participating networks, such as place of employment, location of work, or common interest. These sites have enabled social interactions to go beyond the traditional venues of one's community, work, and home settings. These social networking sites have created new societies based upon diverse interests such as hobbies and interests. Different organizations are nowadays trying to capitalize on SNSs. IBM, for example, has a talent acquisition center in second life, which is a social networking site itself. Infosys, another large multinational in India, has leveraged social networking sites and social media in their "inform to engage" campaign inside the organization as shared by Nandita Gurjar, SVP \& Group HR head- Infosys in Nasscom HR Summit 2013. The unions can follow this social trend, and these social networking sites can be leveraged for a drive for voice and better working conditions at work. It needs to be emphasized, however, that this is not the same as arguing that unions have to set up Facebook pages for workers. Rather, it is about appropriating the characteristics and power of the "SNS trend" and applying them to the "intention" unions offer both workers and (crucially) to firms as well. These characteristics are as follows:

- SNSs are simple to use and cheap to acquire without being simplistic. That is, one can go back to Google or Facebook and receive different benefits each time.

- It has got wide reachability, and it is an amazingly fast-medium where any information can be shared instantly.

- It is a common platform where individuals or groups can customize according to their needs.

- The entry costs for SNSs members are low to nonexistent. There is no real monetary penalty to leaving SNSs either, which means one can try it at least for the first time are more likely to try it for the first time.

This list of SNSs society attributes has some potential for transfer to the problem of acquiring more new trade union members. In previous studies, it has mentioned that British union membership decline [6,7, and 5], "loss of membership" has remained constant for close to thirty years in Britain. During that time, union density reached a flat terrain and began its sturdy decline. How was it possible? The overall cause was the growth in "never membership." That is, persons who entered the labor and they never had a unionized job. In India, the unionized trend, to some extent, coincides with these mass social trends. "Never membership" is a challenge for trade unions in India, and they can exploit SNSs to address this challenge. 


\section{CONCLUSION}

There are major challenges in addressing the issue of decline in union density, mainly "in India. To date, the agenda of labor law and certain central government policies of the country has been dominated by a fascination with preventing and settling industrial disputes. For instance, Indian labor law still requires government permission for layoffs (which are only allowed for 180 days with compensation) and for retrenchment and workplace closure. Dispute resolution mechanisms still require that strikes be withdrawn when conciliation begins [28]. The regulative machinery is always supportive of the employers. Business-government coalitions at the state level also play their role. Post globalization, a couple of states in the country have changed their labor laws and policies to make it simpler for employers to deal with unions, an important issue in drawing foreign investment. For example, Maharashtra has streamlined union recognition procedures to facilitate a single bargaining agent in each workplace, a policy that was long opposed by unions who favored having multiple bargaining agents. The state government of Kerala has guaranteed a no-strike period for foreign investors and banned work stoppages in certain industries (e.g., construction). The state of Uttar Pradesh has indicated its support for employers by mandating that government factory inspectors may enter factories for inspection (to check if labor standards are violated) only after receiving permission from the district magistrate. As correctly pointed out by [2], it is hard to lay off or retrench workers in India. This is one of the prominent reasons for which trade unions are not very successful in India. In this adverse environment, trade unions have to find a solution to the challenge of declining unionization. Unions have to organize workers and convince workers and firms of unionism's benefits. This is true not only in India but anywhere that it becomes difficult to add new members under traditional approaches, especially when there is a less supportive social environment that does not readily highlight the positive attributes of having a union. Though we have offered a characterization of a modern social phenomenon in terms of using SNSs that may give unions some hope of attracting millions of new members, unfortunately, we do not know what a new model of unionism that borrows from the success of Facebook and Twitter type social networks would look like. Common preferences made by a mass of workers require common experiences, which, in turn, generate common expectations, that may require a change like work as well.

This paper does not end with an answer or with a ready-made solution to the problems faced by Indian trade unions; rather, here, an indication has been made in a direction where unions could glance seriously to find an encouraging social phenomenon upon which to toggle onto and also realize from. If social networking sites are the equivalent of the Coney Island weekend retreat, then unions need to learn about what attracts their potential target members out to the twenty-first-century beachfront.

\section{REFERENCES}

[1] Adler, P. S., and Kwon, S. W. (2002). Social capital: Prospects for a new concept. Academy of management review, 27(1), 17-40.

[2] Bamberger, P. A., Biron, M., \& Meshoulam, I. (2014). Human resource strategy: Formulation, implementation, and impact. Routledge.

[3] Borgatti, S. P., Mehra, A., Brass, D. J., and Labianca, G. (2009). Network analysis in the social sciences. science, 323(5916), 892-895.

[4] Brass, D. J. (2009). 10. Connecting to brokers: strategies for acquiring social capital. Social capital: Reaching out, reaching in, 260.

[5] Bryson, A. and Gomez, R. (2005), 'Why Have Workers Stopped Joining Unions?' British Journal of Industrial Relations, Vol. 43, No. 1 (March), pp. 67-92. 
[6] Bryson, A., Freeman, R., Gomez, R., \& Willman, P. (2019). The twin-track model of employee voice: An anglo-American perspective on union decline and the rise of alternative forms of voice. In Employee Voice at Work (pp. 23-50). Springer, Singapore.

[7] Budd, J. W., Lamare, J. R., \& Timming, A. R. (2018). Learning about democracy at work: Cross-national evidence on individual employee voice influencing political participation in civil society. ILR Review, 71(4), 956-985.

[8] Burt, R. S. (1997). A note on social capital and network content. Social networks, 19(4), 355373.

[9] Burt, D. R. (2001). Bandwidth and echo: Trust, information, and gossip in social networks.

[10] Coleman, J. S. (1988). Social capital in the creation of human capital. American journal of sociology, 94, S95-S120.

[11] Fieseler, C., and Fleck, M. (2013). The pursuit of empowerment through social media: Structural social capital dynamics in CSR-blogging. Journal of business ethics, 118(4), 759-775.

[12] Gurjar, N. (2013), 'Social Networking: Leveraging or Lamenting?'. NASSCOM HR SUMMIT, Chennai, India.

[13] Hiers, W., and Kuruvilla. S. (2000), Globalization and Industrial Relations in India. ILO:Bangkok.

[14] International Labour Office (1997) World Labour Report 1997-98. Industrial Relations, Democracy, and Social Stability. Geneva.

[15] International Labour Office. Social Dialogue. http://www.ilo.org/public/english/dialogue/themes/sd.html Key Results on Employment and Unemployment Fifth Quinquennial Survey (July 1993 - June 1994 ): NSS Fiftieth Round.

[16] Kaplan, A. M., and Haenlein, M. (2010). Users of the world, unite! The challenges and opportunities of Social Media. Business Horizons, 53(1), 59-68.

[17] Kearns, G. S., and Lederer, A. L. (2003). A resource-based view of strategic IT alignment: how knowledge sharing creates a competitive advantage. Decision Sciences, 34(1), 1-29.

[18] Leana C. R., Ahlbrandt, R. S., and Murrell, A. J., (1992), The effects of employee involvement programs on unionized workers' attitudes, perceptions, and preferences in decision-making. Academy of Management Journal, Vol. 35, pp. 861-873.

[19] Nahapiet, J., and Ghoshal, S. (1998). Social capital, intellectual capital, and the organizational advantage. Academy of management review, 23(2), 242-266.

[20] Noronha, E.; D'Cruz, P. 2017. 'New Identities require new strategies. Union formation in the IT/ITES sector'. In S. George and S. Sinha (eds). Redefined labor spaces. New York/New Delhi: Routledge.

[21] Putnam, R. D. (1995). Tuning in, tuning out: The strange disappearance of social capital in America. PS: Political science \& politics, 28(4), 664-684.

[22] Sridhar, R.; Panda, S. 2014. 'Contract Employees', Indian Journal of Industrial Relations, 50 (2), pp. 204-212.

Van Dijk, J. (2012). The network society. Sage Publications.

[23] Van Hoye, G., Van Hooft, E. A., and Lievens, F. (2009). Networking as a job search behavior: A social network perspective. Journal of Occupational and Organizational Psychology, 82(3), 661-682.

[24] Visser, J. (2019). Can unions revitalize themselves?. International Journal of Labour Research, 9(1/2), 17-48.

[25] Wallerstein, M., \& B. Western (2000). 'Unions in decline: what has changed and why?' Annual Review of Political Science, Vol. 3, pp.355-377.

[26] Wilks, L. (2011). Bridging and bonding: Social capital at music festivals. Journal of Policy Research in Tourism, Leisure and Events, 3(3), 281-297. 
[27] Wright, C. F., Wailes, N., Bamber, G. J., \& Lansbury, R. D. (2017). Beyond national systems, towards a 'gig economy'? A research agenda for international and comparative employment relations. Employee Responsibilities and Rights Journal, 29(4), 247-257.

\section{AUTHORS}

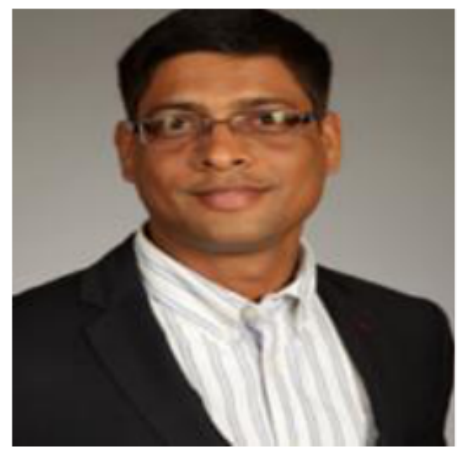

Bimal Chandra Nayak, a research scholar of IIIT Bhubaneswar. An HR leader with diverse industry experience with multinational organizations operating in the areas of Engineering, Information Technology, R\&D, Sales \& Services business. His research area at IIIT Bhubaneswar covers Social media \& its impact on the new economy businesses.

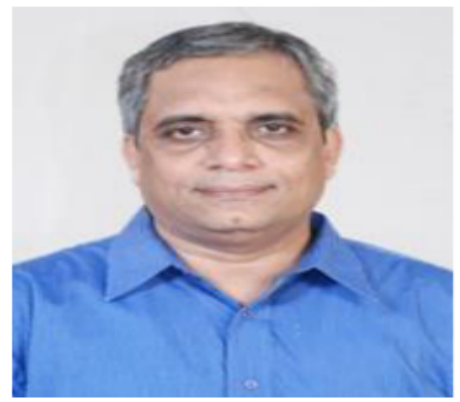

Gopal Krishna Nayak is presently working as Director in IIIT Bhubaneswar. He has received

$\mathrm{Ph} . \mathrm{D}$. degree from IIT Kharagpur and PGDM from IIM, Bangalore. He is the founding member of XIMB, Bhubaneswar. His area of interest is data analytics, soft computing application, ERP, etc

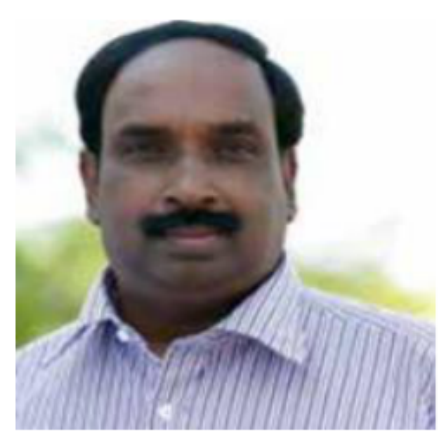

Debasish Jena received his Ph..D. in Computer Science from the NIT, Rourkela, Odisha, India in 2010. He is working as an Associate Professor at IIIT Bhubaneswar, Odisha, India. His area of research interest is in information security, web security, biometric security, bioinformatics and soft computing, machine learning etc 